\title{
TEAR SAMPLE ANALYSIS FOR SARS-COV-2 OF CONFIRMED CASES OF COVID-19
}

\author{
Rai $A,{ }^{1}$ Shrestha $S,{ }^{1}$ Sharma $D,{ }^{1}$ Prasai $G,{ }^{1}$ Mishra $B K,{ }^{2}$ Bhatt $C P^{2}$
}

${ }^{1}$ Department of Ophthalmology, ${ }^{2}$ Department of Microbiology, Kathmandu Medical College, Sinamangal, Kathmandu, Nepal

\begin{abstract}
Researchers in 2004 found that tear flim can be one of the modes of transmission of SARS-CoV. Considering the fact that SARS-CoV-2 is similar to SARS-CoV, it is speculated that there may be a risk of transmission through tear flim in patients with COVID-19. Therefore, this study was conducted to understand whether COVID-19 viral genome is present in the tear film or not. It was a cross-sectional quantitative study done in Kathmandu Medical College Teaching Hospital, Duwakot. Tear sample collection was done using schirmer's strip and conjunctival swab of confirmed COVID-19 positive admitted cases and then the sample was sent for viral genome analysis. Especially designed proforma was used for recording the patient demographics, history, clinical examination findings and investigations results. Data were analyzed using the Statistical Package for the Social Sciences (version 21) and expressed in frequency, percentage and mean. Out of 30 enrolled patients, $23.3 \%(n=7)$ showed positive results in tear RT-PCR test for SARSCoV-2. Among them, 85.7\% $(n=6)$ had positive tear sample RT-PCR on the very first day of sample collection with their CT value in tear sample ranging from 30-35. Patients who were positive were mostly in the age group of $21-30$ years $(71.4 \%)$ and were local vendors by occupation (71.4\%). However, none of the patients had any ocular symptoms. Tear sample analysis with RT-PCR showed 23.3\% positivity for SARS-CoV-2. Early collection and analysis of tear sample can yield maximum positive results therefore tear film could be one of the modes of transmission of SARS-CoV-2 virus.
\end{abstract}

\section{KEYWORDS}

COVID-19, CT value, RT-PCR, SARS-CoV-2, Tear film

\section{CORRESPONDING AUTHOR}

Dr. Ashesh Rai,

Resident, Department of Ophthalmology,

Kathmandu Medical College,

Sinamangal, Kathmandu, Nepal

Email: joinashesh65@gmail.com

Orcid ID: https://orcid.org/0000-0001-7601-4482

DOI: https://www.doi.org/10.3126/nmcj.v23i1.36219 


\section{INTRODUCTION}

An outbreak of a novel coronavirus disease emerged in December 2019 which later turned into pandemic. ${ }^{1}$ COVID-19 is a highly contagious disease which may lead to death due to acute respiratory distress syndrome. ${ }^{2}$ Though the primary site of offense is the respiratory system, other systems like ocular and gastrointestinal have also been seen to be involved. ${ }^{3,4,5}$

The transmission through infected ocular fluid has always been a topic of controversy. Recently, ocular surface tissues have shown to have both Angiotensin Converting Enzyme 2 and cellular serine protease suggesting them to be a possible site of entry and reservoir. Nasolacrimal duct has continuous mucosa with the puncta which may allow spread of infection. However, there are limited data regarding involvement of eye in SARS-CoV-2 infection till now. ${ }^{6}$ Hence, this study was conducted to find out if SARS-CoV-2 genome is present in ocular fluid like tear flim.

\section{MATERIALS AND METHODS}

The study was conducted on COVID-19 confirmed patient at Kathmandu Medical College Teaching Hospital, Duwakot, Bhaktapur. The tear sample analysis was performed by RT-PCR. It was a cross-sectional quantitative study conducted from June 2020 to August 2020. Convenience sampling was done. It was ensured that participants were fully informed about the study and gave their consent to participate in the study. Approval from Institutional Review Committee of Kathmandu Medical College Teaching Hospital was obtained before starting the study. Especially designed proforma was used for recording the patient demographics, travel history or history of exposure, clinical examination findings and investigation report. Data were analyzed using the Statistical Package for the Social Sciences (version 21).

The ocular samples were taken from both the eyes of each patient wearing full personal protective equipment (PPE kit) by a single person to avoid interpersonal bias. Tear samples were collected using conjunctival swabs and Schirmer's strips (Whatmann filter paper no. 41). Each strip was folded from one end and inserted at the junction of middle two third and lateral one third of the lower lid of both the eyes without topical anesthesia and then waited for 30 seconds to 1 minute for reflex tear secretion. Conjunctival swab was used to collect the tear film sample from the lower fornix by rotating the swab stick 360 degrees. Both the Schirmer's strip and the swab stick were placed in the viral transport media (NodFord) which was then placed in cold chain box and transferred to the PCR lab in Duwakot for detection of COVID-19 viral genome. Then the sample was processed for nucleic acid extraction using viral nucleic acid extraction kit (Hipure). After that the extracted RNA was analyzed with RT-PCR reagent (Shenzhen Yillifang) and double gene detection system (N gene and ORF $1 \mathrm{ab}$ gene). The sample was declared positive if $\mathrm{CT}$ value was $\leq 40$ and negative if CT value was $>40$.

\section{RESULTS}

A total of 30 RT-PCR positive patients were enrolled in the study. Age of the patients ranged from 16 to 63 years with a mean age being $33.23 \pm 12.13$ years.

Table 1: Distribution of age in groups

\begin{tabular}{|lcc|}
\hline Age range in years & Frequency & $\mathbf{\%}$ \\
\hline $\mathbf{1 1 - 2 0}$ & 2 & 6.7 \\
$\mathbf{2 1 - 3 0}$ & 15 & 50.0 \\
$\mathbf{3 1 - 4 0}$ & 7 & 23.3 \\
$\mathbf{4 1 - 5 0}$ & 3 & 10.0 \\
$\mathbf{5 1 - 6 0}$ & 1 & 3.3 \\
$\mathbf{6 1 - 7 0}$ & 2 & 6.7 \\
Total & $\mathbf{3 0}$ & $\mathbf{1 0 0 . 0}$ \\
\hline
\end{tabular}

Maximum number of patients ( $n=15,50.0 \%)$ were in the age group of 21-30 years followed by $31-40$ years $(n=7,23.3 \%)$.

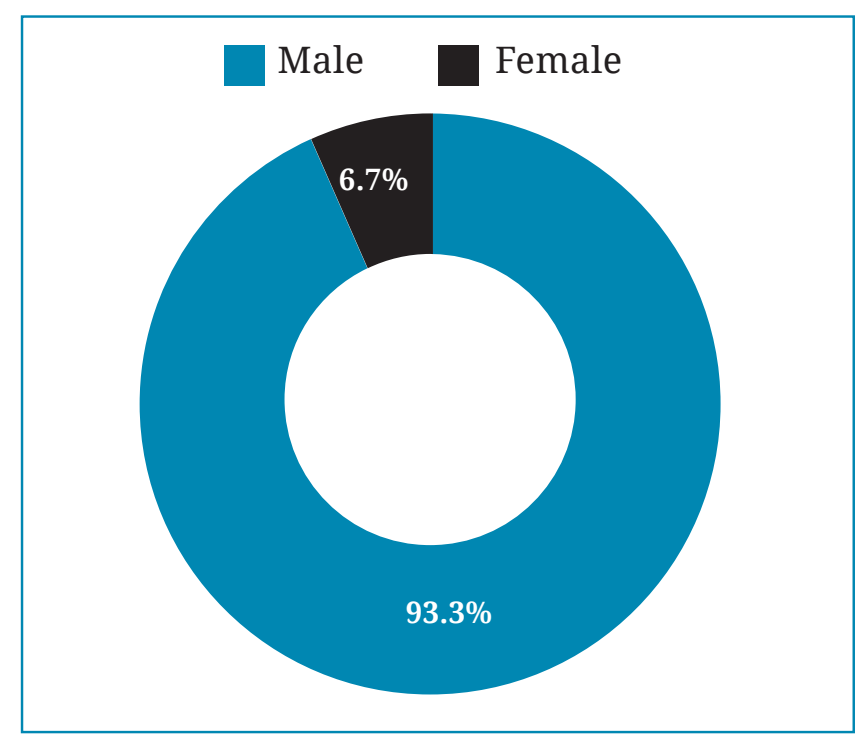

Fig. 1: Distribution of gender

Male preponderance, with $93.3 \%(n=28)$ and M: F ratio of 14:1. 


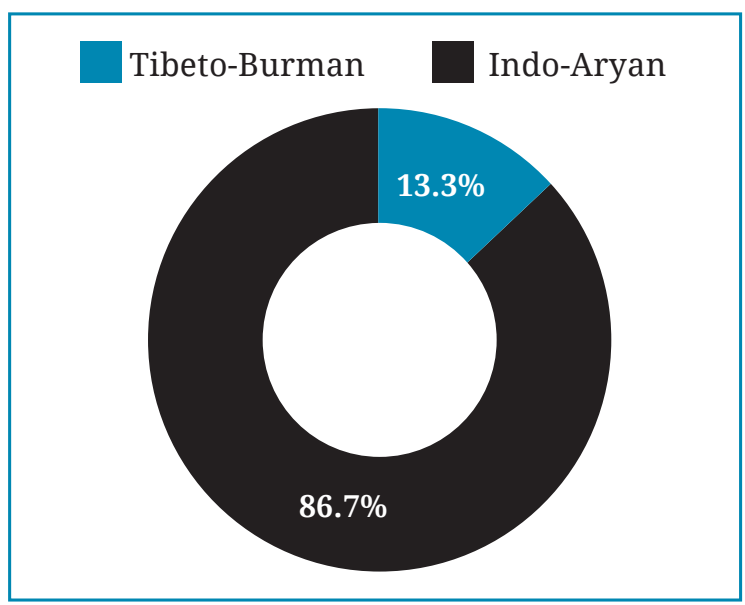

Fig. 2: Distribution of ethnicity

Indo-Aryan ethnicity was more common among the patients (86.7\%) (Fig. 2).

\begin{tabular}{|lcc|}
\multicolumn{3}{c}{ Table 2: Distribution of occupation } \\
\hline Occupation & Frequency & \% \\
\hline Social worker & 6 & 20.0 \\
Vendors & 11 & 36.7 \\
Laborer & 9 & 30.0 \\
Student & 2 & 6.7 \\
Health worker & 1 & 3.3 \\
Banker & 1 & 3.3 \\
Total & $\mathbf{3 0}$ & $\mathbf{1 0 0 . 0}$ \\
\hline
\end{tabular}

Local vendors were the most susceptible group $(n=11,36.7 \%)$ followed by laborers and social workers respectively for COVID-19.

\begin{tabular}{|lcc|}
\hline Table 3: Distribution of address according \\
to district \\
District & Frequency & \% \\
\hline Kathmandu & 16 & 53.3 \\
Bhaktapur & 12 & 40.0 \\
Lalitpur & 2 & 6.7 \\
Total & $\mathbf{3 0}$ & $\mathbf{1 0 0 . 0}$ \\
\hline
\end{tabular}

Maximum number of patients were from Kathmandu ( $\mathrm{n}=16,53.3 \%)$.

\begin{tabular}{|lcc|}
\hline Table 4: & Status of RT- PCR of tear sample \\
\hline PCR & Frequency & \% \\
\hline Positive & 7 & 23.3 \\
Negative & 23 & 76.7 \\
Total & $\mathbf{3 0}$ & $\mathbf{1 0 0 . 0}$ \\
\hline
\end{tabular}

Among the enrolled patients, $23.3 \%$ tested positive for SAR-CoV-2 in the tear sample. However, none of the patient had ocular complaints.

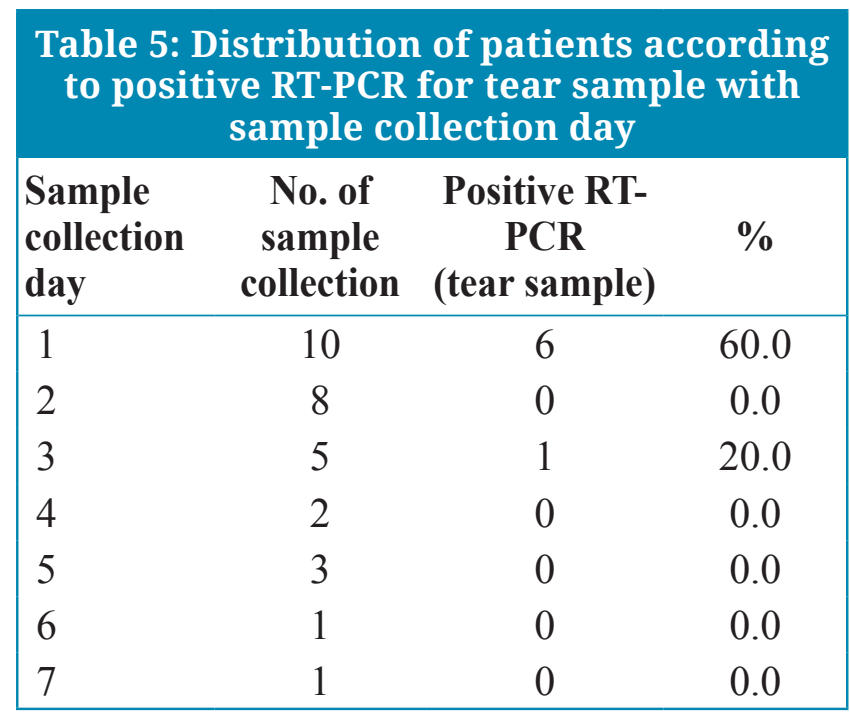

In day one, the RT-PCR was positive in $6(60 \%)$ cases out of 10 samples collected and in day three, it was positive in only $1(20.0 \%)$ case out of five samples. However, tear samples collected in day 2 didn't yield any positive results.

$\mathrm{CT}$ value was given by $\mathrm{N}$-Gene and ORF $1 \mathrm{ab}$ gene, the value of $\leq 40$ was taken as positive for RT-PCR tear sample analysis. Patients were mostly in the age group of $21-30$ years (71.4\%). and local vendor by occupation (71.4\%).

\begin{tabular}{|lcccc|}
\multicolumn{5}{c|}{ Table 6: Cyclic Threshold (CT) value of patients with tear sample being positive for } \\
COVID-19 in relation to their age and occupation
\end{tabular}




\section{DISCUSSION}

The most effective technique for detecting viral nucleic acid is RT-PCR. This method of detection is very simple, convenient and efficient because of its high sensitivity and specificity. ${ }^{9,10}$ However, sample contamination and damage to genetic material while collection may give rise to false positive and false negative results. ${ }^{11}$ Researchers in $2004 \mathrm{AD}$ found that tear sample tested positive in patients with SARS. ${ }^{12}$ As the chromosome of SARS-CoV-2 is $82.0 \%$ similar to that of SARS-CoV, it is assumed that tear fluid could be one of the mode for transmission of the disease. ${ }^{13}$ And also we cannot ignore the fact that many ophthalmologists were found to be infected during the examination procedure too. ${ }^{6}$

It was a cross-sectional quantitative study conducted in Kathmandu Medical College Teaching Hospital, Duwakot, designated as level-1 COVID hospital by Government of Nepal. We enrolled 30 confirmed RT-PCR positive patients. Both schirmer's strip and conjunctival swabs were used for collection of tear sample. In our study, age ranged from 16 to 63 years with mean age of 33.2 years which is somehow in accordance with the national data. ${ }^{14}$ This can also be attributed to the fact the most of the patients were young migrant workers returning from the foreign countries. ${ }^{14,15}$ However similar studies conducted by Ping WU et al and Xia J et al showed mean age of 65.8 years and 54.5 years respectively which is quite high than ours. ${ }^{3,16}$ In our study, male preponderance was seen with 28 patients (93.3\%), which is in accordance with that seen in Nepal as a whole, but worldwide the prevalence is same in both the genders with the severity being more in males. ${ }^{14,17}$ Local Vendors $36.6 \%$ followed by laborers $30.0 \%$ were the most susceptible groups based on occupation. These people working hand to mouth were the most affected economically due to the lockdown and had to go out for work making them more susceptible to the virus. Ensuring proper hygiene and social distancing at the site of vending can be an effective measure to lower the risk of transmission.

Tear sample PCR was found to be positive in $7(23.33 \%)$ cases which is higher than another study conducted at China by Ping WU et al which yielded positive results in $5.2 \%$ of patients. ${ }^{3}$ Similarly, another study conducted at Hangzhou, China showed positive result in only 1 case out of 30 patients. ${ }^{16}$ However, in contrast to these studies, researchers from Singapore also conducted RT- PCR in tear sample and found none of the samples had positive results $(0.0 \%) .{ }^{18}$ Only two patients with positive tear
RT-PCR had systemic symptoms of COVID-19 like fever, sore throat and dry cough in our study. None of the patients were found to have ocular symptoms. Chinese researcher Ping WU found ocular manifestations in 12(31.6\%) of the total 38 clinically confirmed COVID-19 patients. ${ }^{3}$ However, they have not compared the status of tear film RT-PCR with ocular manifestations. Similarly,study done by Xia et al showed presence of conjunctivitis in only 1 patient which tested positive for tear RT-PCR. ${ }^{16}$

Among the seven positive cases seen in our study, six (85.7\%) tested positive on the first day of sample collection, i.e one day after they have received a positive report for their nasopharyngeal swab samples. This is approximately 5-7 days of the day of being infected by the virus. A high viral load during this period of initial infection is possibly the reason why tear samples showed viral RNA even in asymptomatic patients. The sole patient testing positive on the third day may be attributed to him being tested earlier than the recommended testing period having more viral load then other being tested negative on that same very day. This is more evident as all tear sample positive cases had CT value of < 40. Hence, viral load and the day of infectivity may give a hint for tear film secretion being a possible mode of SAR-CoV-2 transmission. In our study of seven positive patients, most were in age group of 21-30 years and local vendors by occupation so they were more prone to exposure to virus as people of this age group are more active and mobile and have higher chances of exposure.

Since most of our cases were asymptomatic or only mildly symptomatic, the positive tear film tests were probably seen only on the first day primarily. The likely drawbacks of our study can be the small sample size and uncertainty of the exact day of infectivity of the patient. In addition to this, more severe cases with higher viral load were not present in our center due to it being a level I COVID hospital.

In conclusion, our study shows that there are chances of detecting SARS-CoV-2 RNA if tear sample were collected and analyzed early in the course of the disease. COVID-19 can be transmitted through the tear film in the early phase of the disease. The viral loads in conjunctival specimens may gradually decrease over time with less risk of transmission.

\section{ACKNOWLEDGMENT}

We would like to acknowledge KMC Teaching Hospital and faculty members of Department 
of Microbiology for letting us conduct this research.We would specially like to thank Prof. Dr. Chanda Karki, Dr. Md. Harun Husen and Dipendra Dhakal for the support and guidance during the research work and all COVID-19 patients for allowing to take tear sample for the research purpose.

\section{REFERENCES}

1. Chen Lu, Liu M, Zhang ZN et al. Ocular manifestations of a hospitalized patient with confirmed 2019 novel coronavirus disease. Br J Ophthalmol 2020; 104: 748-51. https://doi.org/10.1136/bjophthalmol-2020316304PMid:32265202 PMCid:PMC7211077

2. Seah I, Agrawal R. Can the Coronavirus Disease 2019 (COVID-19) Affect the Eyes? A Review of Coronaviruses and Ocular Implications in Humans and Animals. Ocular Immunol Inflam 2020; 00 (00): 15. https://doi.org/10.1 080/09273948.2020.1738501PMid:32175797 PMCid:PMC7103678

3. Wu P, Duan F, Luo C et al. Characteristics of ocular findings of patients with coronavirus disease 2019 (COVID-19) in Hubei Province, China. JAMA Ophthalmol2020;138:575.https://doi.org/10.1001/ jamaophthalmol.2020.1291PMid:32232433 PMCid:PMC7110919

4. Zhou Y, Zeng Y, Tong Y, Chen CZ. Ophthalmologic evidence against the interpersonal transmission of 2019 novel coronavirus through conjunctiva. Med Rxiv 2020; 2002(2011): 20021956. https://doi. org/10.1101/2020.02.11.20021956

5. Zhang $\mathrm{X}$, Chen $\mathrm{X}$, Chen $\mathrm{L}$ et al. The evidence of SARS-CoV-2 infection on ocular surface. Elsevier 2020. https://doi. org/10.1016/j.jtos.2020.03.010PMid:32289466 PMCid:PMC7194535

6. 6.Lu C-W, Liu X-F, Jia Z-F. 2019-nCoV transmission through the ocular surface must not be ignored. Lancet 2020; 395: e39. https://doi.org/10.1016/ S0140-6736(20)30313-5

7. Zhou L, Xu Z, Castiglione GM, Soiberman US, Eberhart CG, Duh EJ. ACE2 and TMPRSS2 are expressed on the human ocular surface, suggesting susceptibility to SARS-CoV-2 infection. Ocul Surf 2020; 18: 537-44. https://doi. org/10.1016/j.jtos.2020.06.007PMid:32544566 PMCid:PMC7293510

8. Ma D, Chen $\mathrm{CB}$, Jhanji $\mathrm{V}$ et al. Expression of SARS-CoV-2 receptor ACE2 and TMPRSS2 in human primary conjunctival and pterygium cell lines and in mouse cornea. Eye(Lond) 2020; 34: 1212-9. https://doi.org/10.1038/s41433-020-09394 PMid:32382146 PMCid:PMC7205026

9. Corman VM, Landt O, Kaiser $\mathrm{M}$ et al. Detection of 2019 novel coronavirus (2019-nCoV) by realtimeRT-PCR. EuroSurveill 2020; 25: 23-30.https:// doi.org/10.2807/1560-7917.ES.2020.25.3.2000045
10. Chen N, Zhou M, Dong X et al. Epidemiological and clinical characteristics of 99 cases of 2019 novel coronavirus pneumonia in Wuhan, China: a descriptive study. Lancet 2020; 395(10223): 50713. https://doi.org/10.1016/S0140-6736(20)302117

11. Lin C, Ye R, Xia YL. A meta-analysis to evaluate the effectiveness of real-time PCR for diagnosing novel coronavirus infections. Genet Mol Res 2015; 14: 15634-41. https://doi.org/10.4238/2015. December.1.15PMid:26634531

12. Loon SC, Teoh SCB, Oon LLE, Thoe SYS, Ling $\mathrm{AE}$, Leo YS. The severe acute respiratory syndrome coronavirus in tears. $\mathrm{Br} J$ Ophthalmol 2004; 88: 861-3. https://doi. org/10.1136/bjo.2003.035931PMid:15205225 PMCid:PMC1772213

13. Chan JFW, Kok KH, Zhu Z et al. Genomic characterization of the 2019 novel humanpathogenic coronavirus isolated from a patient with atypical pneumonia after visiting Wuhan. Emerg Microbes Infect 2020; 9: 221-36. https:// doi.org/10.1080/22221751.2020.1719902PM id:31987001 PMCid:PMC7067204

14. Banerjee I, Robinson J, Kashyap A, Mohabeer P, Shukla A, Leclézio A. The changing pattern of COVID-19 in Nepal: A Global concern-A Narrative Review. NepalJEpidemiol 2020;10;845-55.https:// doi.org/10.3126/nje.v10i2.29769PMid:32874698 PMCid:PMC7423402

15. Chalise HN. COVID-19 situation and challenges for Nepal. Asia Pac J Public Health 2020. https://doi. org/10.1177/1010539520932709PMid:32545991

16. Xia J, Tong J, Liu M, Shen Y, Guo D. Evaluation of coronavirus in tears and conjunctival secretions of patients with SARS-CoV-2 infection. J Med Virol 2020; 92: 589-94. https://doi.org/10.1002/ jmv.25725PMid:32100876 PMCid:PMC7228294

17. Gebhard C, Regitz-Zagrosek V, Neuhauser HK, Morgan R, Klein SL. Impact of sex and gender on COVID-19 outcomes in Europe. Biol Sex Differ 2020; 11: 29. https://doi.org/10.1186/s13293-02000304-9PMid:32450906 PMCid:PMC7247289

18. Jun Seah IY, Anderson DE, Zheng Kang AE et al. Assessing Viral Shedding and Infectivity of Tears in Coronavirus Disease 2019 (COVID-19) Patients. Amer Acad Ophthalmol 2020; 127: 977-9. https://doi.org/10.1016/j. ophtha.2020.03.026 P Mid:32291098 PMCid:PMC7151491 